\title{
A GENETIC ALGORITHM BASED APPROACH TO CONSTRUCTING CONTAINER SHIPPING NETWORKS WITH EMPTY CONTAINER REPOSITIONING AMONG CALLING PORTS*
}

\author{
by Koichi SHINTANI ${ }^{* *}$, Akio IMAI ${ }^{* * *}$, Etsuko NISHIMURA ${ }^{* * *}$ and Stratos PAPADIMITRIOU ${ }^{* * *}$
}

\section{Introduction}

This paper addresses the issue of designing service networks for container liner shipping while explicitly taking into account empty container repositioning and container fleet size. The container shipping industry has been witnessing an overwhelming growth and prosperity in recent years mainly due to China's economic boom. To cope with the ever increasing container traffic demand, liner companies are increasing their capacity by investing in new containerships.

The sea container industry is confronted with the problem of allocating empty containers. However, load rejection is a very unlikely practice in case of shortage of available empty containers because of the intensive competition in the market. Consequently, an important decision at the operational level is how to transfer empty containers and/or lease containers in a timely and efficient manner. The above context of the container shipping allows us to distinguish the entire shipping network design problem, which includes decisions on the voyage itinerary, ship size and calling frequency, into two sub-problems: one for the design of networks to serve loaded container traffic and the other for networks to assign empty container traffic to meet cargo demand. In fact, to the authors' knowledge, all existing studies related to empty container traffic focus only on empty container repositioning. The former sub-problem is summarized by three review papers ${ }^{3), 8,9}$. The latter is researched by Cheung and Chen ${ }^{1)}$, Choong et al. ${ }^{2)}$, Crainic et al. ${ }^{4)}$, Gavish ${ }^{5)}$, and Imai and Rivera ${ }^{7)}$.

Separation of empty container movements from full container movements is appropriate if all cargo demand is satisfied. Contrary to this, if we are able to forgo unprofitable cargo demand whose generated revenue is offset by the associated costs of empty container relocation, the examination of both full and empty traffic is required in designing underlying service networks because of the interaction between full and empty traffic.

In a strategic decision making of shipping network, the container fleet size problem, which decides the number of containers required to meet future cargo demand, should be considered to design containership routing networks. If liner shipping companies provide a large fleet of owned containers, then they have a small burden of empty container movements. On the other hand, a smaller owned container fleet is likely to result in hiring a large number of short-term leased containers. From the strategic viewpoint, therefore, the container fleet size should be taken into consideration in a shipping network design. However, in our previous study ${ }^{10}$, the consideration of container fleet size was ignored, mainly because shipping operators handle an enormous scale of own or long-term leased containers for their business and they give up optimizing the container fleet size. Due to this reality, the investment costs in the container fleet turn out to be the sunk costs. As a result, the operators are free from thinking about the container fleet. Thus, this study attempts to optimize the container fleet size under the overall optimization of shipping network architecture by including the cost of own container fleet.

In this paper, we propose a design method for containership routing networks incorporated with empty container repositioning among calling ports and container fleet size, which is modeled on a Knapsack problem basis and is reduced to a location routing problem. The proposed problem is solved by a heuristic based on genetic algorithms (GA), in order to find a set of calling ports, an

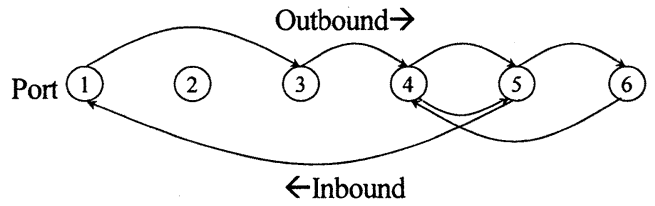

Figure 1. Example of ship's itinerary

\footnotetext{
*Keywords: Port Planning, Maritime Transportation

**Member of JSCE, M. Eng., Shipping Technology Department, Oshima National College of Maritime Technology

(1091-1 Komatsu, Suo-oshima, Oshima, Yamaguchi 742-2193 Japan, Tel/Fax: +81-820-74-5502, E-mail: shintani@oshima-k.ac.jp)

$* * *$ Member of JSCE, Dr. Eng., Faculty of Maritime Sciences, Kobe University

(5-1-1 Fukaeminami, Higashinada, Kobe 658-0022 Japan)

****Non-member, Ph.D., Department of Maritime Studies, University of Piraeus

(80 Karaoli and Dimitriou Str., GR185 32 Piraeus, Greece)
} 
associated port calling sequence, the number of ships by ship size category and resulting cruising speed to be deployed in the service networks, and container fleet size, with the objective of profit maximization for a liner shipping company. An application of the problem to container transportation in Southeast Asia is presented. In the numerical experiments, results are examined by various factors, which may affect formation of the voyage routes and the proportion of containers in loaded and empty states carried on board the ships.

\section{Problem description}

Most container shipping companies assign a number of ships on a particular trade route, which is characterized by two end ports (i.e., head-end and tail-end ports) and many intermediate calling ports in between. In order to maximize profit, the companies must decide: ports to be called and the order of call sequence for the chosen ports. As the problem must determine the above decision factor, it is the so-called location routing problem. However, in practical situations, a decision maker of a liner shipping company builds shipping networks based on the rule of thumb and his experiences. Such a decision making process does not guarantees the efficient and optimal solution; therefore, the decision maker should employ the efficient decision method like the one we propose in this paper to maximize the company's profit with considering empty container repositioning and container fleet size. In most existing voyage routes, all ports to be called on the way from the head-end port to the tail-end port (referred to as outbound direction) are not always called on the way back to the head-end port (referred to as inbound direction), as shown in Fig. 1, where ports 1 and 6 are the head-end and tail-end ports.

The model maximizes profit by forming a single route, which does not necessarily call at all the ports in the trade area. The model assumes a weekly cargo demand for all origin/destination pairs. Other assumptions are as follows:

(i) The demand for empty containers at a port, at a specific point of time, is the differential of the total traffic originating from the port and the total loaded container traffic arriving at the port for that specified time period.

(ii) All the cargo traffic emanating from a port is satisfied if that port is selected on the route.

(iii) If a sufficient container quantity is not available at a port, the shortage is fulfilled by leasing containers.

(iv) The total loaded and empty containers transported by a ship must not exceed the ship's capacity.

As mentioned, this model assumes that the shipping line does not necessarily call at all ports in the trade area. However, in reality, the line priorities and/or constraints for selecting calling ports. For instance, the line has priority customers in a specific port and therefore it must call at that port, while this decision does not result in a large profit from a narrower viewpoint. However, such a situation makes the problem rather complex; therefore we assume an ideal decision-making.

\section{(1) Formulation}

The problem of deciding an optimal route (i.e., choosing an optimal set of calling ports and associated calling sequence of ports), can be formulated as a Knapsack problem and a Flow problem. The Knapsack problem approach has been widely used not only in ship scheduling problems but also in other general scheduling problems.

The problem consists of two parts. One part is the lower-problem, which identifies the optimal calling sequence of ports for a specific group of calling ports. The other is the upper-problem, which is reduced to the Knapsack problem and chooses the best set of calling ports that associate to the calling sequence found in the lower-problem. The upper-problem [UP] and the lower-problem [LP] may be formulated as follows:

$$
\begin{array}{lll}
\text { [UP] Maximize } & \sum_{k \in V} Z^{k} \rho_{k} \\
& & \\
\text { subject to } & \sum_{k \in V} \rho_{k}=1 \\
& \rho_{k} \in\{0,1\} \quad \forall k \in V,
\end{array}
$$

where $V$ is the set of groups of calling ports, each of which associates the optimal voyage route that is identified by the [LP]; and $\rho_{k}=1$ if the route associated with a candidate group of calling ports $k$ is selected, $=0$ otherwise.

Given a set of calling ports, [LP] constructs the optimal calling sequence, which associates with it the resulting profit as the objective function value $Z^{k}$. For simplicity in formulating [LP], the objective function is denoted as $Z$. Then, [LP] may be formulated as follows:

[LP] Maximize $Z=R-C(\mathbf{y})-P(\mathbf{y})-H(\mathbf{y})$ 


$$
\begin{array}{lll}
\text { subject to } & \sum_{j \in N} y_{i j}=\sum_{j \in N} y_{j i} & \forall i \in N, \\
& \sum_{i \in S} \sum_{j \notin S} y_{i j} \geq 1 & \forall S \subset N, \\
& y_{i j} \in\{0,1\} & \forall i, j \in N, \\
& \mathbf{y}=\left\{y_{i j} \mid i \in 1, \ldots, N ; j \in 1, \ldots, N\right\}
\end{array}
$$

where $N$ is the set of calling ports for $k \in V ; S$ is a nonempty subset of $N ; C($.$) is the shipping cost function of selected$ $\operatorname{arcs}(i, j) ; H($.$) is the holding cost function of own container fleet; P($.$) is the empty container related (or leasing) cost$ function of selected arcs $(i, j) ; R$ is the revenue associated with $k \in V$; and $y_{i j}=1$ if a ship sails on arc $(i, j)=0$ otherwise.

The decision variables are $y_{i j}$ s. The objective function (4) is the maximization of the total profit. Constraint set (5) ensures that a calling ship at a port must depart from that port. As shown in Fig. 1 where it is envisaged that $N$ contains all ports 1 through 6 except for 2, the route must connect all the ports in $N$. Constraints (6), therefore, guarantee that all the ports are connected each other through the formed route. The constraints, in other words, guarantee that there are more than one directed arc between a node in any subset of ports, $S$, and the one not in $S$, resulting in that there is no such sub-tour that does not visit all the nodes in $N$. Eq. (8) defines a vector $\mathbf{y}$ to be comprised of $y_{i j}$ s for a formed voyage route. Also, the calling sequence is associated with $y_{i j} \mathrm{~s}$.

Given a freight rate for the origin-destination port pair, the revenue generated is defined by the set of calling ports with the assumption that the published rate is applied independent of the cargo traffic itinerary depending of the resulting voyage route. $R$ is defined as follows:

$$
R=\sum_{i \in N} \sum_{j \in N} F R_{i j} x_{i j}
$$

where $F R_{i j}$ is the freight rate of cargo (US\$/TEU) from ports $i$ to $j$ and $x_{i j}$ is cargo traffic (TEU) from ports $i$ to $j$, which is associated with origin-destination pair of calling ports for [LP] since we assume that a ship undertakes all the cargo demand emanating from ports to be called.

The shipping cost depends on a variety of ship factors and transportation demand on the route. In this paper, therefore, the shipping cost is expressed as the sum of the costs regarding arcs on candidate routes, which are associated with $y_{i j} \mathrm{~s}$. In the following subsections (2) - (4), $y_{i j}$ s are not explicitly utilized in each cost formulation. This is because the costs are composed, based on a specific shipping route that is assumed to have been constructed already by determining $y_{i j} \mathrm{~s}$.

Notice that the costs (except the holding cost of own container fleet) and revenue described above are a multiplication of the profit, the cost per voyage, and the cost of a deployed ship. This enables us to evaluate only the revenue and those cost per ship. In the numerical experiments, the total revenue and costs, in order to be accorded as values per year, are multiplied by the number of voyages.

In the following subsections, we provide relevant cost functions. See Imai ${ }^{6)}$ and Shintani et al. ${ }^{10)}$ for details.

\section{(2) Shipping cost function}

The shipping cost is made up by two components: operating and capital costs. In general, the capital cost includes the cost regarding the ship itself, while the operating cost includes the costs of fuel, lubricant and port entry. These costs are defined as below:

$$
\begin{aligned}
& C=C S+C P \\
& C S=C^{C}+C^{F} \\
& C P=C^{E}+C^{H}
\end{aligned}
$$

where $C S$ is the ship related costs; $C P$ is the port related cost; $C^{C}$ is ship's other costs, which are not incurred in proportion to the cruse distance $\left(C^{C}=C^{M}+C^{D}+C^{R}+C^{I}+C^{P}\right) ; C^{D}$ is the ship's depreciation cost; $C^{E}$ is the port entry cost; $C^{F}$ is the fuel and its related cost; $C^{H}$ is the cargo handling cost; $C^{I}$ is the insurance cost; $C^{M}$ is the crew cost; $C^{R}$ is the interest; and $C^{P}$ is the repair and maintenance cost

\section{(3) Leasing cost function}

Liner shipping companies are generally faced with an enormous level of imbalanced cargo traffic between trade sections. This 


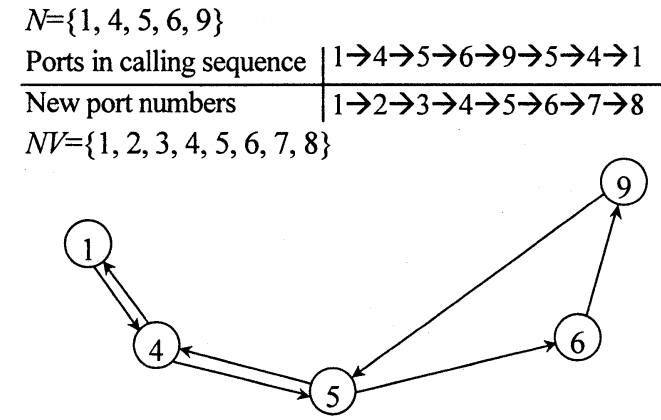

(a) Original calling route

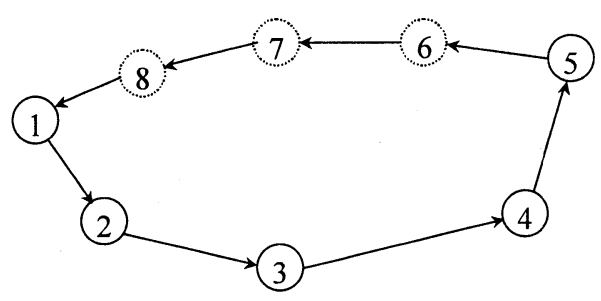

(b) Corresponding virtual calling sequence

Figure 2. Calling sequence transformation

imbalance creates some costs (referred to as leasing costs) as a number of unproductive tasks have to be performed such as the reposition of empty containers from excessive points to demand points, storage of empty containers in place for future demand and leasing containers to meet urgent cargo demand. For the task of container repositioning we assume that no costs are associated with it, because it is performed using the excess capacity on their own ships.

Fig. 2(b) shows the virtual calling sequence, which was converted from the original calling sequence of Fig. 2(a). The virtual calling sequence includes virtual nodes that represent nodes to be visited more than once in the original calling route. The set of nodes in the virtual sequence is denoted by $N V$.

The leasing cost function, $P$, is given by the following equation where the virtual calling sequence shown in Fig. 2 is assumed:

$$
\begin{array}{ll}
P=\sum_{i \in N V} a_{i} L S_{i} & \\
S_{i}=\max \left\{D_{i}-P_{i}, 0\right\} & \forall i \in N V, \\
L S_{i}=S_{i}-\sum_{j \in B^{i}} w_{j i} & \forall i \in N V, \\
\sum_{p \in B^{i}+\{i\}} \sum_{q \in L^{i}}\left(x_{p q}+w_{p q}\right) \leq C A P & \forall i \in N V,
\end{array}
$$

where $a_{i}$ is the short-term leasing cost at port $i$ (US\$/TEU); $L S_{i}$ is the number of lease containers at port $i$ (TEU); $N V$ is the set of nodes in the virtual calling sequence; $B^{i}$ is the subset of $N V$, which are called before port $i ; L^{i}$ is the subset of $N V$, which are called not before port $i ; D_{i}$ is the cargo traffic departing from port $i ; P_{i}$ is the cargo traffic destined for port $i ; S_{i}$ is the number of demanded containers at port $i ; w_{j i}$ is the number of empty containers carried from ports $j$ to $i$; and $C A P$ is the ship capacity.

Eq. (14) defines the shortage of containers. If $D_{i}-P_{i}$ is negative, i.e., the number of containers to be requested is less than the number of available containers, $S_{i}$ is set to zero; otherwise $S_{i}$ is set $D_{i}-P_{i}$. Variable $D_{i}$ and $P_{i}$ are associated with cargo demand emanating from ports to be called. Eq. (15) defines the number of containers to be leased. Inequality (16) guarantees that empty containers are transported in an excessive space of a ship. Note that $w_{j i}$ s are auxiliary variables, which are fixed when variables $y_{i j}$ s are fixed.

\section{(4) Holding cost function of own container fleet}

Once shipping companies obtain a fleet of containers they must, in general, keep them in use for more 10 years. However, it is practically impossible to take into account future empty movements, to determine the container fleet size. From this, given a weekly cargo demand as mentioned in section 3 , we can roughly calculate the own fleet size and it's holding cost with a distribution of full and empty containers for a candidate route. Also, we assume a container departure from a port to a shipper or consignee and its return from the customer occur when a ship calls at the port.

A flow conservation at a port is given by eqs. (17) and (18), respectively. In a case of own container shortage, we lease containers to meet all the cargo demand at port $i$.

$$
\begin{array}{ll}
A_{i}=R_{i}+G_{i}+S T_{i}^{\prime} & \forall i \in N V, \\
F_{i}=A_{i}-O_{i}-S T_{i}+L S_{i} & \forall i \in N V,
\end{array}
$$




$$
\begin{array}{ll}
E_{i}=\max \left\{P_{i}-D_{i}, 0\right\} & \forall i \in N V, \\
S T_{i}=E_{i}-\sum_{j \in L^{i}} w_{i j} & \forall i \in N V,
\end{array}
$$

where $A_{i}$ is the number of empty containers available in port $i$ (TEU); $E_{i}$ is the number of excess containers at port $i ; G_{i}$ is the number of empty containers coming by the ship to port $i$ from others; $F_{i}$ is the number of empty containers for the next shipments; $O_{i}$ is the number of empty containers going by ship from port $i$ to others; $R_{i}$ is the number of empty containers returning from consignees to port $i ; S T_{i}$ is the number of containers stored at port $i ; S T_{i}^{\prime}$ is the number of empty containers stored in port $i$ from previous planning period. Both eqs. (17) and (18) contain the excessive empty containers $S T_{i}^{\prime}$ and $S T_{i}$, respectively. The proposed model only reflects the container flow during one voyage, but the flow conservation must be kept over multiple voyages from practical viewpoint. This enforces $S T_{i}=S T_{i}^{\prime}$ and this equality allows us to reduce the container fleet size by $\sum_{i} S T_{i}$. However, a certain amount of $S T_{i}$ should be held as safety stock. (i.e., $S T_{i}$ is added to eq. (24)). Eq. (19) specifies the number of containers to be stored at a port $i$. Eq. (20) defines shortage of empty containers.

The holding cost function of own container fleet, $H$, is made up by two components: retaining cost of own container fleet and storage cost for the buffer stocks at each port. These costs are defined as below:

$$
\begin{array}{ll}
H=C^{P} T F+\sum_{i \in N V} b_{i} B S_{i} & \\
T F=\sum_{i \in N V}\left(O F_{i}+B S_{i}\right) & \\
O F_{i}=F_{i}+O_{i}-L S_{i}+D_{i} & \forall i \in N V, \\
B S_{i}=b r_{i} F_{i}+S T_{i} & \forall i \in N V .
\end{array}
$$

where $C^{P}$ is the average retaining cost of container per year (US\$/TEU/year); $b_{i}$ is the storage cost per year at port $i$ (US\$/TEU/year); TF is the total own fleet size (TEU); $O F_{i}$ is the own fleet size at port $i$ (TEU) and $B S_{i}$ is the number of buffer stocks at port $i$ (TEU); $b r_{i}$ is a rate for buffer stock at port $i$.

Eq. (22) defines the total own fleet size adding the buffer stocks. Eq. (23) defines a distribution of full and empty containers at port $i$. The turnaround time is assumed 7 days as a container is delivered from a port to shippers and returns from the shippers to port, while the required number of containers must be equal to cargo traffic destined, $D_{i}$. In eq. (24) given a rate for buffer stock, the number of buffer stocks is defined as a multiplication of the rate and the number of next shipments at specific port. We assume that $b r_{i}$, a rate for buffer stock at port $i$, is set as $b r_{i}=1.0$ for each port. We establish $B S_{i}$, because in general, shippers require empty containers much earlier than the scheduled time of empty container delivery for their export and also because empty containers to deliver to shippers may be short due to delayed arrival of ships that bring empty containers to the ports.

\section{Solution procedure}

This section describes a solution procedure for this problem, which is categorized as a combinatorial optimization problem; therefore efficient exact algorithms are unlikely to exist. From this point of view, this paper employs a heuristic method GA to nearly optimize the solution. As mentioned in the previous section, the problem is modeled by two sub-problems simply because of difficulty in the problem formulation. However, since the GA directly generates solutions for the problem as will be shown later, we identify the solution for the problem at a time, not by using a sequential process such as finding the solution of the lower sub-problem [LP] and then the one of the upper sub-problem [UP]. We do not describe the details of our GA procedure because of its popularity.

\section{(1) Genetic representation}

Fig. 3 illustrates the corresponding formation of Fig. 1. The length of the string of digit is the number of candidate calling ports, regardless of being selected or not, from one port to another including intermediate ports on the way to the latter and those on the way back to the former. Note that similar to calling formation described in section 3.3, a specific port is assigned different numbers whenever called in the entire voyage. In Fig. 3, the ports, which are not all called necessarily, on the way back from ports 6 to 1 of Fig. 1 have the numbers 7 through 11 associated with them.

Therefore, for example, port 5 in Fig. 1 has two different numbers 5 and 7 in Fig. 4 . An arc from ports $m$ to $n$ as shown in Fig. 1 is presented as $n$ is housed in $m$ th locus. Such linkages between two calling ports are chained to each other to form an 
$\begin{array}{lllllllllll}\text { Locus: } & 1 & 2 & \mathbf{3} & \mathbf{4} & \mathbf{5} & \mathbf{6} & \mathbf{7} & \mathbf{8} & 9 & 10\end{array}$

Chromosome: \begin{tabular}{|l|l|l|l|l|l|l|l|l|l|}
\hline 3 & 5 & 4 & 5 & 6 & 8 & 11 & 7 & 11 & 9 \\
\hline
\end{tabular}

Figure 3. Chromosome representation

(5) (4) (3) (2)

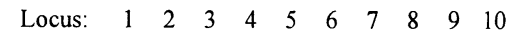

\begin{tabular}{|c|c|c|c|c|c|c|c|c|c|c|c|}
\hline Parent1: & 3 & 5 & 4 & 5 & 6 & 8 & 11 & 7 & 11 & 9 & P1: $1 \rightarrow 3 \rightarrow 4 \rightarrow 5 \rightarrow 6 \rightarrow 4 \rightarrow 5 \rightarrow 1$ \\
\hline Parent2: & 4 & 4 & 2 & 6 & 6 & 9 & 9 & 11 & 8 & 11 & P2: $1 \rightarrow 4 \rightarrow 6 \rightarrow 3 \rightarrow 4 \rightarrow 1$ \\
\hline spri & 4 & 4 & 2 & 6 & 6 & 8 & 11 & 7 & 8 & 11 & 01: $1 \rightarrow 4 \rightarrow 6 \rightarrow 4 \rightarrow 5 \rightarrow 1$ \\
\hline
\end{tabular}

Figure 4. Example of crossover processing

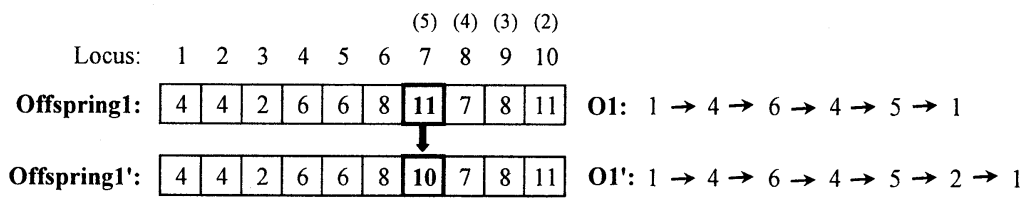

Figure 5. Example of mutation processing

entire voyage. Loci, which are equivalent to uncalled ports, house any port numbers arbitrarily.

\section{(2) Fitness and selection}

A fitness value reflects the goodness of an individual, compared with the other individuals in the populations. In this study, a fitness value corresponds to a value of the objective function, namely, the company's profit. We adopt two selection methods: an elitist-preserve strategy and a roulette-wheel selection. The former method is used when the two higher rank individuals are unconditionally preserved to the next generation and the latter is employed to randomly pick up a superior individual from the remainder.

\section{(3) Crossover}

The crossover scheme should be capable of reproducing a new feasible solution (or offspring) by combining good characteristics of both parents. A generated offspring should be presented a round trip on a complete route. In order to keep the feasibility, the crossover operation performs in the following manner (Fig. 4 shows an example with a new offspring created by crossover and presents the resulting routes): First, define port 1 as the starting port of a voyage. Focusing on digits in the locus corresponding to the origin port in the two selected parents, select a digit arbitrarily from them and store the selected digit in that locus of offspring. Second, focusing on digits, from the parents, located in a locus, which is defined by the digit just housed in offspring; choose either digit randomly and store it in the same locus of that offspring. Repeat this procedure until a round trip is completely formed. Finally in loci equivalent to unvisited ports, digits from either of the parents in the corresponding loci are stored. Furthermore, if an infeasible chromosome is generated, perform crossover procedure from the beginning once again.

\section{(4) Mutation}

Fig. 5 presents an example of processing of the mutation operator and associated routes. Mutation randomly chooses a locus and houses a digit in that locus that is chosen randomly from any of the ports in the service area. If an infeasible chromosome is generated, operate mutation again.

\section{Computational experiments}

This section presents an application of the problem to container transportation in Southeast Asia. We considered a number of impact factors to the formation of a shipping route. In order to assess the solution quality of the GA, we compared approximate 
solutions by the GA with the optimal solutions of the same problems being solved by the Brute force method. Due to the computational limitation of these methods, we tested small problems with 5-8 ports in the trade area. As a result, the GA found the optimal solution for every problem.

Based on preliminary experiments, parameters of the GA were set as follows: population size $=300$, maximum number of generations $=200$, crossover rate $=0.9$ and mutation rate $=0.08$.

\section{(1) Parameter settings for the experiments}

Settings of major parameters for the experiments are as follows:

(i) Potential calling ports (20 ports): Tokyo, Yokohama, Shimizu, Nagoya, Osaka, Kobe, Moji, Hakata, Busan, Shanghai, Keelung, Kaohsiung, Hong Kong, Ho Chi Minh, Manila, Leam Chabang, Bangkok, Port Klang, Jakarta and Singapore; (ii) the time horizon: 52 weeks; (iii) the calling frequency per year: 52; (iv) the turn around time of a ship: less than or equal to 21 days; (v) ship sizes: 500, 1000, 1500, and 2000 TEUs; (vi) the handling cost at each port: US\$200/TEU; (vii) the short-term leasing cost at each port $\left(a_{i}\right)$ : US\$300/TEU; and (viii) the storage cost at each port $\left(b_{i}\right)$ : US $\$ 0.5 / \mathrm{TEU} /$ day.

We obtained data for setting parameters (vi) - (viii) based on surveys with shipping and stevedoring companies as well as port authorities in Japan.

\section{(2) Case studies}

Throughout the experiments the sensitivity of some factors was examined to determine their influence on the solution. The first factor is the impact of the leasing cost coefficient $\left(a_{i}\right)$ (i.e., leasing cost). Companies consider the cost related to empty containers as very seriously nowadays. It is likely that each company assigns a different value to the repositioning cost. Thus, we consider three levels for the empty container-related cost such as: basic cost, twice as much as the basic cost and four times as much.

The second factor is the impact of taking empty containers into consideration. In other words, we look into the difference in the profit gained by the two proposed solutions: the one identified by the problem we propose (case 1) and the other by the problem without consideration of empty container movement (case 2). Calculations for case 2 were also performed by GA, but the problem employed for them did not take into account empty container distribution (i.e., variable $w_{i j}$ s are not included in the formulations), the associated empty container-related costs (or leasing costs) and the holding cost of own container fleet, in the objective function. Note that the problem without empty distribution is hereafter referred to as based problem. After the based problem was solved, the necessary empty container traffic was distributed in the shipping network, whilst relevant constraints were satisfied, and relevant leasing costs and the holding cost of own container fleet were added to the profit of the resulting objective function value. The profit resulting from the above process is the one for case 2 . It seems that in order to keep the sailing schedule, ships must increase cruising speed if the handling time increases, since more empty containers are handled due to the resulting inefficient empty traffic. At the same time, increasing movement of empty containers may also raise the operating costs and the holding cost of own container fleet, for the same reason.

\section{(3) Experimental results}

Port-to-port traffic of loaded containers per week is estimated by using several data sources such as the United Nations ${ }^{11)}$ and the official home page of each port, etc. Table 1 shows the weekly throughput of import and export containers at each port based on the estimated traffic.

We first look into the best ship size in TEUs. We computed a specific problem sample by GA 50 times with varying the initial arrangement of genes. Fig. 6 portrays the convergence of profit in average of 50 runs during genetic iterations by four different ship sizes. For each ship size, we assumed three different levels of leasing cost (indicated by $x 1, x 2$ and $x 4$ ). While there are no significant differences in profit by the different leasing cost levels, as expected the highest profit is achieved with the employment of the least cost ship. The most profitable ship size is 1000TEUs.

Table 2 illustrates comparisons between cases 1 and 2 by the most profitable ship size, 1000TEUs, showing the 5 best solutions for each case. The best solutions in case 1 are centered on the number of deployed ships $=3$, whilst the figures may be fractional. As mentioned before, case 2 solutions are calculated by adding empty container distribution to the solutions of the based problem and the holding cost of own container fleet. Note that in case 2, the based problem does not take into account empty container distribution and therefore transports more loaded containers. As expected, case 1 results in being more profitable than case 2 , as it consists of less revenue but also of much less shipping, the leasing and holding costs. Thus, case 1 provides a smaller container 
Table 1. Weekly throughput at ports (TEUs)

\begin{tabular}{ccccccccccccccccccccc}
\hline Port & 1 & 2 & 3 & 4 & 5 & 6 & 7 & 8 & 9 & 10 & 11 & 12 & 13 & 14 & 15 & 16 & 17 & 18 & 19 & 20 \\
\hline Import & 879 & 906 & 196 & 382 & 282 & 1008 & 196 & 288 & 1925 & 779 & 325 & 595 & 1634 & 112 & 382 & 83 & 913 & 573 & 175 & 1338 \\
Export & 1076 & 1181 & 271 & 790 & 506 & 1533 & 260 & 382 & 1467 & 914 & 417 & 539 & 392 & 97 & 624 & 69 & 901 & 548 & 92 & 912 \\
\hline
\end{tabular}

1: Tokvo. 2: Yokohama. 3: Shimizu. 4: Nagova. 5: Osaka. 6: Kobe. 7: Moii. 8: Hakata. 9: Busan. 10: Shanghai

11: Keelung. 12: Kaohsiung. 13: Hong Kong. 14: Ho Chi Minh. 15: Manila. 16: Leam Chabang. 17: Bangkok

18: Port Klang. 19: Jakarta. 20: Singapore
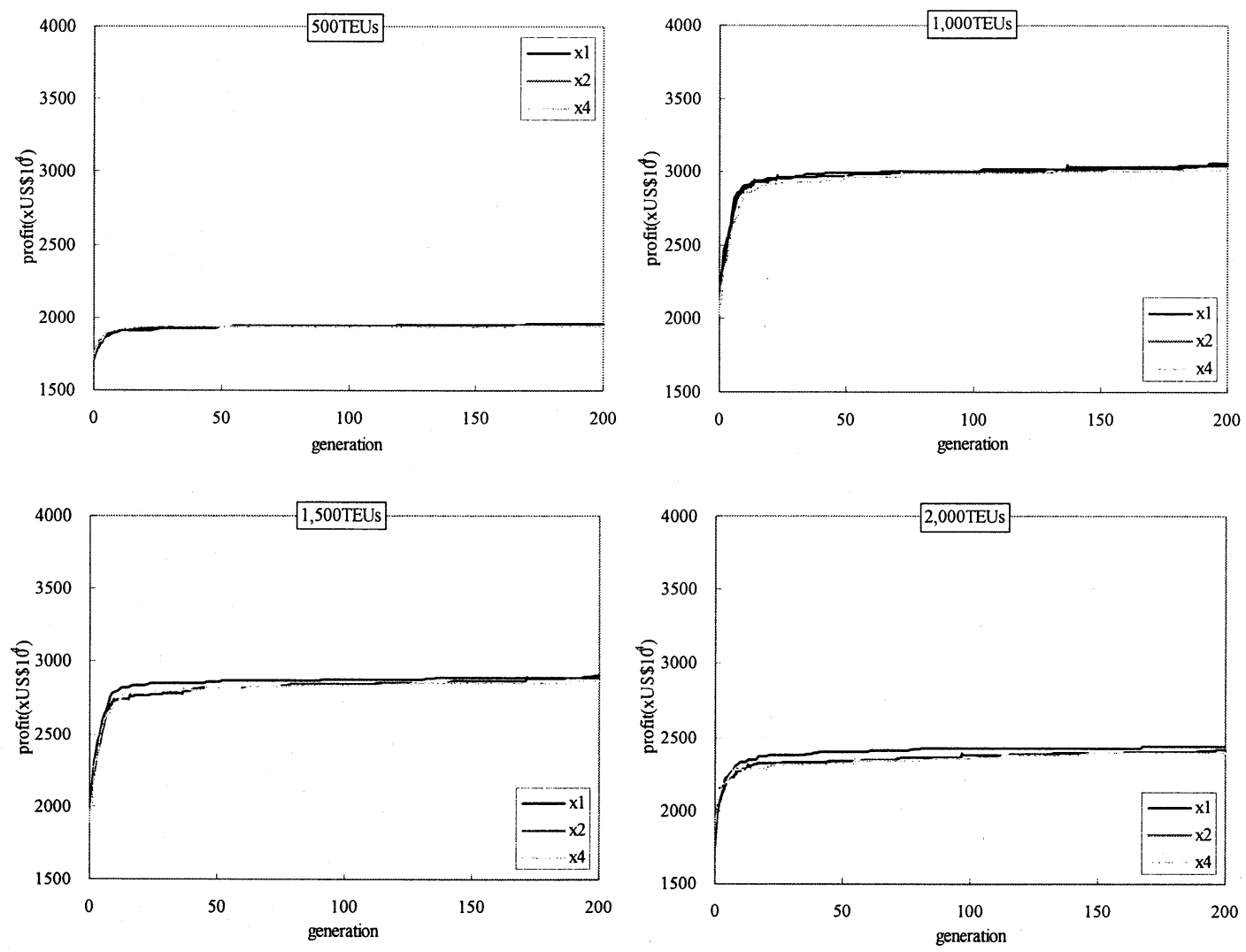

Figure 6. Convergence of GA solution by different ship sizes

Table 2. Comparison between cases 1 and 2 by 1000 TEU ship

\begin{tabular}{|c|c|c|c|c|c|c|c|c|c|c|}
\hline case \# & Sol.\# & The calling sequence & Profit & Revenue & $\begin{array}{l}\text { Shipping } \\
\text { cost }\end{array}$ & $\begin{array}{l}\text { Leasing } \\
\text { cost }\end{array}$ & $\begin{array}{l}\text { Holding } \\
\text { cost }^{*}\end{array}$ & $\begin{array}{c}\text { Cruising } \\
\text { speed }\end{array}$ & $\begin{array}{l}\text { Fleet } \\
\text { size }\end{array}$ & Distance \\
\hline & & & $\left(x U S \$ 10^{4}\right)$ & $\left(\mathrm{xUS} \$ 10^{4}\right)$ & $\left(x U S \$ 10^{4}\right)$ & $\left(\mathrm{xUS} \$ 10^{4}\right)$ & $\left(x U S \$ 10^{4}\right)$ & (knots) & & (nautical miles) \\
\hline \multirow[t]{5}{*}{1} & 1 & $1-2-17-20-15-11-2-1$ & 3759.0 & 10394.0 & 6298.8 & 1.9 & 334.3 & 20.7 & 3 & 6672 \\
\hline & 2 & $1-2-5-16-17-20-11-5-2-1$ & 3568.4 & 10417.7 & 6489.3 & 2.9 & 357.1 & 20.7 & 3 & 6385 \\
\hline & 3 & $1-2-5-17-20-11-5-2-1$ & 3566.5 & 10229.9 & 6312.1 & 2.6 & 348.7 & 20.3 & 3 & 6365 \\
\hline & 4 & $1-2-5-11-14-17-20-11-5-2-1$ & 3550.7 & 10461.0 & 6542.7 & 3.7 & 363.9 & 20.8 & 3 & 6283 \\
\hline & 5 & $1-2-5-11-20-17-5-2-1$ & 3509.3 & 10222.3 & 6350.4 & 4.7 & 357.9 & 20.3 & 3 & 6365 \\
\hline \multirow[t]{5}{*}{2} & 3 & $1-2-3-11-20-17-6-2-1$ & 3307.6 & 11034.2 & 7336.8 & 8.7 & 381.1 & 22.4 & 3 & 6379 \\
\hline & 4 & $1-2-3-4-17-20-6-2-1$ & 3216.0 & 10729.5 & 7129.6 & 11.7 & 372.2 & 22.3 & 3 & 6590 \\
\hline & 5 & $1-4-6-20-17-6-2-1$ & 3202.5 & 10761.1 & 7175.6 & 10.6 & 372.4 & 22.4 & 3 & 6635 \\
\hline & 2 & $1-2-4-17-20-6-5-2-3-1$ & 3024.9 & 11151.0 & 7686.4 & 12.9 & 426.8 & 24.0 & 3 & 6767 \\
\hline & 1 & $1-2-13-20-17-6-2-1$ & 3019.7 & 11488.2 & 8032.0 & 7.1 & 429.4 & 24.3 & 3 & 6640 \\
\hline
\end{tabular}

1: Tokyo, 2: Yokohama, 3: Shimizu, 4: Nagoya, 5: Osaka, 6: Kobe, 7: Moji, 8: Hakata, 9: Busan, 10: Shanghai,

11: Keelung, 12: Kaohsiung, 13: Hong Kong, 14: Ho Chi Minh, 15: Manila, 16: Leam Chabang, 17: Bangkok,

18: Port Klang, 19: Jakarta, 20: Singapore

*: the holding cost of own container fleet 
fleet than case 2. Interestingly, case 2 has a complicated and inefficient empty container distribution. As the based problem has not considered empty traffic, a lot of loaded containers are transported due to the fact that no ship space is reserved for empty container transfer in the solution of the based problem and consequently a huge shortage of empty containers is observed. This shortage is covered through expensive leasing.

\section{Conclusions}

This study addressed the problem of container liner shipping network construction by explicitly taking into account empty container distribution and container fleet size. Whilst there is a huge literature on ship routing and scheduling problems, few studies treat the design of container shipping network and none of them incorporate the problem of repositioning and leasing of empty containers and container fleet size. In this paper, this problem was dealt with by forming a shipping network with the assumption that necessary empty container repositioning is performed using spare space on ships operated and containers are leased when empty containers do not arrive at the demand points in time. $\mathrm{GA}$ is employed for implementing a solution method for the problem.

Based on the computational experiments that we conducted, the following conclusions can be reached: Due to the empty container flow and container fleet size that was treated in this problem, the handling time and associated costs at ports are smaller than those by using the based problem. As a result, the problem with empty distribution results in being able to cruise at a slower speed due to the efficient empty container distribution and thus save considerably the fuel costs. Moreover, the problem with considering the container fleet size reduces the primary investment cost.

The proposed approach is very useful in assessing potential shipping networks from both strategic and tactical viewpoints, since the design of the container shipping network without consideration of the empty container traffic eventually becomes very costly due to less efficient empty container distribution associated with the resulting network.

In this study, a uniform volume of cargo demand in each calling port is assumed for every voyage whilst there are seasonal cargo fluctuations in cargo demand over several voyages in practical situations. Therefore, the consideration of such seasonal fluctuations seems to provide a more insightful solution in terms of trade-offs of the leasing and holding costs. A mitigation of this restriction may be an interesting topic for future research.

\section{Acknowledgement}

The authors would like to thank Mr. Mitsuaki Ichikawa, Tokuyama Kairiku Unso Corp., for his helpful expert opinions concerning the buffer stocks.

\section{References}

1) Cheung, R. K., Chen, C.: A two-stage stochastic network model and solution methods for the dynamic empty container allocation problem, Transportation Science 32, 142-162. 1998.

2) Choong, S.T., Cole, M. H., Kutanoglu, E.: Empty container management for intermodal transportation networks, Transportation Research 38E, 423-438. 2002.

3) Christiansen, M., Fagerholt, K., Ronen, D.: Ship routing and scheduling: Status and perspective, Transportation Science 38 (1), 1-18. 2004.

4) Crainic, T. G., Gendreau, M., Dejax, P.: Dynamic and stochastic models for the allocation of empty containers, Operations Research 41, 102-126. 1993.

5) Gavish, B.: A decision support system for managing the transportation needs of a large corporation, AIIE Transactions 13, 61-85. 1981 .

6) Imai, A.: A study of optimal planning of infrastructure and operations for container transportation, Ph.D thesis, Kyoto University. 1989. (in Japanese)

7) Imai, A., Rivera, F.: Strategic fleet size planning for maritime refrigerated containers, Maritime Policy and Management 28 (4), 361-374. 2001.

8) Ronen, D.: Cargo ships routing and scheduling: Survey of models and problems, European Journal of Operations Research 12, 119-126. 1983.

9) Ronen, D.: Ship scheduling: The last decade, European Journal of Operations Research 71, 325-333. 1993.

10) Shintani, K, Imai, A., Nishimura, E., Papadimitriou, S.: The container shipping network design problem with empty container repositioning, Transportation Research Part E. (to appear)

11) United Nations: International trade statistics yearbook, 1998. 


\title{
A GENETIC ALGORITHM BASED APPROACH TO CONSTRUCTING CONTAINER SHIPPING NETWORKS WITH EMPTY CONTAINER REPOSITIONING AMONG CALLING PORTS
}

\author{
Koichi SHINTANI $^{* *}$, Akio IMAI ${ }^{* * *}$, Etsuko NISHIMURA ${ }^{* * *}$ and Stratos PAPADIMITRIOU ${ }^{* * * *}$
}

This paper addresses the design of container liner shipping service networks by explicitly taking into account empty container repositioning and container fleet size. Two key and interrelated issues of deployments of ships and containers are usually treated separately by most existing studies on shipping network design. In this paper, both issues are considered simultaneously. The problem is formulated as a two-stage problem: the upper-problem being formulated as a Knapsack problem and the lower-problem as a Flow problem. A genetic algorithm based heuristic is developed for the problem. Through a number of numerical experiments that were conducted it was shown that the problem considering empty container repositioning provides a more insightful solution than the one without.

\section{遺伝的アルゴリズムによる空コンテナの回送を考慮したコンテナ船の航路計画 ${ }^{*}$}

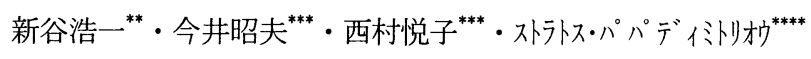

これまで航路計画と空コンテナの回送は別問題として扱われてきたことに鑑み, 本船による空コンテナの 回送と自社コンテナの保有規模を考慮した航路計画モデルを検討した. さらに，そのモデルを東南アジア航 路に適用して, 空コンテナの回送が航路形成に及ぼす影響を分析した. そのモデルは二段階の問題として定 式化され, 上位問題はナップサック問題, 下位問題はフロー問題として表現される. この問題に対し, 効率 的に解を得ることを目的として遺伝的アルゴリズムを採用した. いくつかの要因に着目して数值実験を行っ たところ, 空コンテナの回送を考慮した航路計画は, それを考慮しない航路計画よりも船社にとって利益を 大きくすることがわかった. 